\title{
日本雪工学会平成15年度総会報告
}

\section{A General Meeting of Japan Society for Snow Engineering in 2003}

平成15年度の総会は，平成15年 6 月 26 日（木）午後 2 時より，東北大学工学部青葉記念会館（仙台市青葉 区荒巻字青葉） 5 階会議室において開催された。開会に先立ち, 沼野総務委員会委員長より, 出席者 34 名, 委任状347通により，会則に基づき総会が成立していることが報告された。続いて，吉野会長の挨拶の後, 会則に従い会長が議長となり，以下の次第に沿って議事が進められた。

次 第 1 . 総会議案
(1) 平成14年度事業報告
（2）平成14年度決算報告
(3) 平成15年度事業計画
(4) 平成15年度予算案
(5) その他

2. 平成14年度日本雪工学会賞授与

議案(1)〜(4)については，すべて原案通り可決された。なお(5)として堀井大会理事（任期 1 年）の再任が提 案され, 了承された。総会議案の審議が終了した後, 平成14年度日本雪工学会賞の選考結果について吉野会 長（表彰委員長代理）より説明があり，以下の 3 件（4名）に対して学会賞が吉野会長より授与された。ま た， 3 名の受賞者から受賞の挨摱があった。

学 術 賞 東北工業大学教授 沼野夏生氏

業績名 豪雪地帯における雪办防災に向けた人文社会科学的研究 北海道大学教授 城 攻氏 北海学園大学教授 桜井修次氏 業績名 効率的な積雪樑観測法および信頼性の高い積雪重量推定法の開発 学術奖励賞 山形大学助手渡邊 洋氏 業績名 地中熱を活用した融雪と路面温度制御に関する研究

総会終了後, 牛後 3 時30分より, 同会場にて社北海道開発技術センターの原 文宏氏を講演者に迎えて, 特別講演会「社会的ジレンマとしての雪問題」が開催された。刺激的な講演内容に触発されて, 約 30 名の聴 講者の中からは活発な質疑があった。

講演会終了後, 午後 4 時 45 分より, 講内の喫茶室「トロイム」に場所を移して想親会がもたれた。参加者 は20名であった。昨年よりやや遅めの時間とあって帰りの交通機関が気になる人もみられたが, 雪工学会の 今後のあり方をめぐってなごやかな中にも熱い議論が交わされていた。 


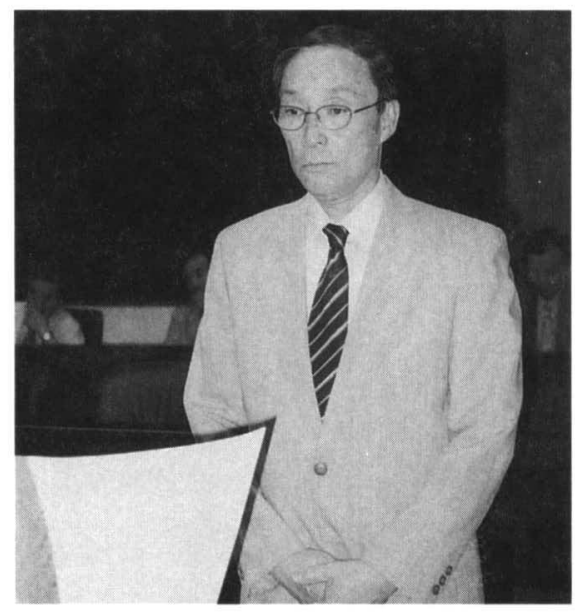

学術賞を受賞した 沼野夏生 氏

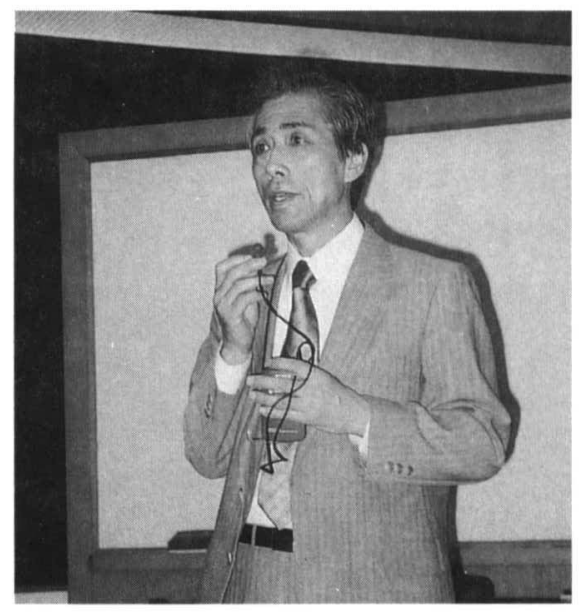

受賞の喜びをスピーチする(学術賞) 桜井修次 氏

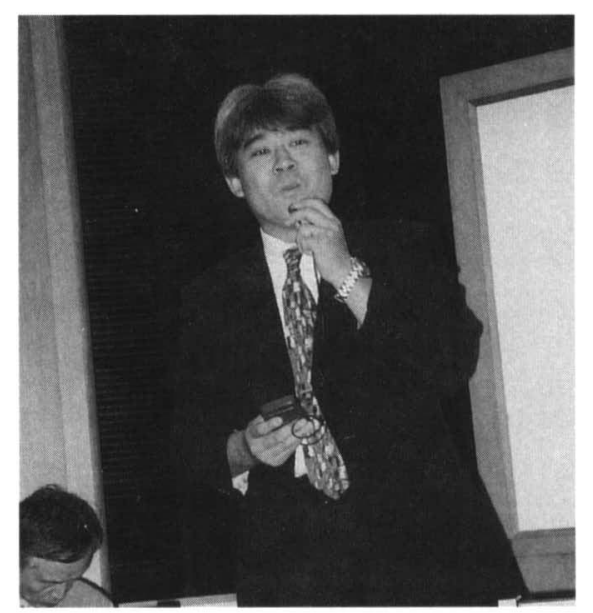

受賞の喜びをスピーチする(学術奨励賞) 渡邊 洋 氏

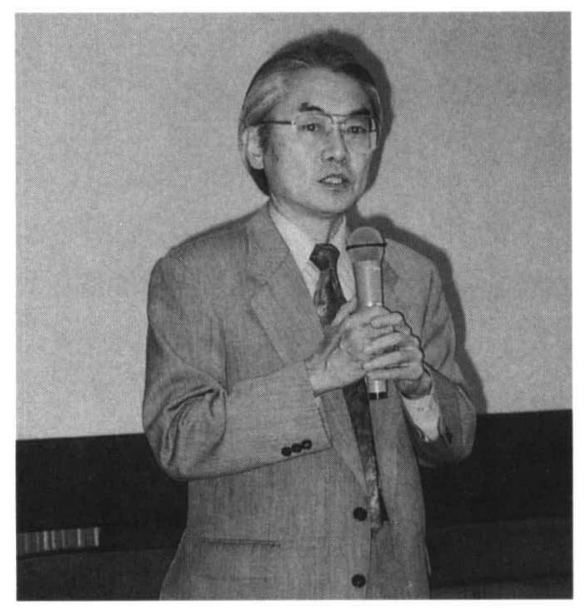

総会の挨拶を行う 吉野 博 会長

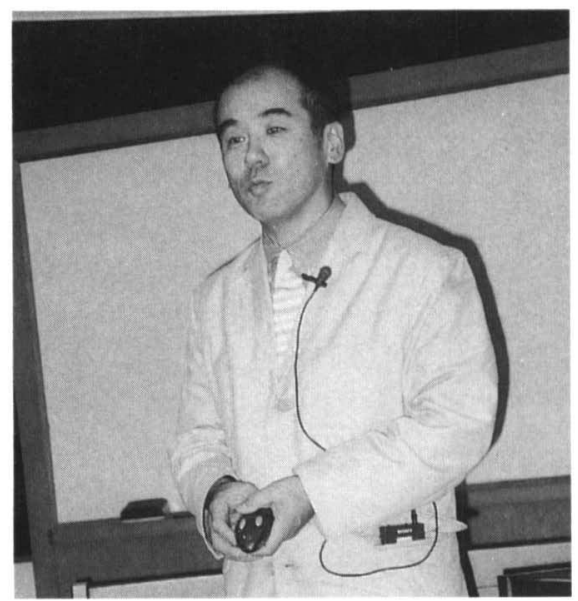

記念講演を行う 原 文宏 氏 


\section{平成 14 年度事業報告}

平成14年度は, 学会事業の活性化と組織の充実, 並びに, 雪工学研究の推進と社会への還元が図られた。 平成14年度の主な事業は以下の如くである。

(1) 総 会

平成14年度総会は以下の如く開催され，以下の 6 議案について審議された。議案については原案通り承認 された。

日 時: 平成 14 年 6 月 14 日

場 所 : 東北大学工学部青葉記念会館

出席者：30名（委任状 372 通）

議 案: 1 . 平成 13 年度事業報告

2 . 平成 13 年度決算報告

3. 会則の一部改訂

4. 平成 14 年度事業計画

5 . 平成 14 年度予算案

6 ，役員の選出

\section{(2) 理 事 会}

理事会は以下の如く開催され，学会の事業・運営について番議された。

○理事会の開催

- 第 1 回 平成 14 年 6 月 1 日 (東北大学 17 名)

- 第2回平成1 4 年 8 月 20 日 (東北工業大学 18 名)

- 第3 回 平成 14 年 12 月 15 日 (岩手大学 20 名)

-第 4 回平成 15 年 3 月 29 日 (東北大学 17 名)

\section{（3）運営委員会 （委員長・吉野 博）}

学会運営の基本方針や具体的活動に関する審議，並びに，理事会議案の作成を行つた。

○運営委員会の開催

・第 1 回 平成 14 年 8 月 20 日 (東北工業大学 9 名)

・第 2 回平成 14 年 10 月 12 日 (東北大学 15 名)

- 第 3 回平成 14 年 12 月 15 日 (岩手大学 11 名)

-第 4 回平成 15 年 3 月 29 日 (東北大学 15 名)

\section{（4） 総務委員会 （委員長・沼野夏生）}

1）各種内規類の整備（継続して内規類の見直しと整備について意見交換を行つた。）

2 ）入会案内の作成（入会案内パンフレットを完成し，岩手大会時に配布した。）

3 ）会長の指示により，雪工学会アクションプラン（仮称）の原案を作成した。

4 ) 運営委員会・理事会の開催準備 


\section{5 ）事務局業務}

（特記事項）第19期学術会議会員候補者として吉野会長を，推薦人として宮内副会長を届出 ○委員会の開催

・第 1 回 平成 14 年 11 月 27 日 (通 信)

・第 2 回 平成 15 年 2 月 8 日 (通 信)

\section{（5）編集委員会 （委員長・高橋 弘）}

学会誌の編集・発行を行った。本学会ホームページの更新および学会誌電子ジャーナル化の準備を行った。 （）委員会の開催

- 第 1 回 平成 14 年 5 月 31 日 (東北大学)

·第 2 回平成 14 年 8 月 27 日 (東北大学)

- 第 3 回 平成 14 年 12 月 6 日 (東北大学)

- 第 4 回 平成 15 年 3 月 3 日 (東北大学)

○学会誌の発行 4 回

主な内容：

4 月号 Vol.18, No.2 (Ser No.63)

論文 2 編

特集『除雪機戌之道路除雪』

7 月号 Vol.18, No.3 (Ser No.64)

論文 3 編

特集『平成14年度日本雪工学会総会報告』

10月号 Vol.18, No.4 (Ser No.65)

『第19回日本雪工学会大会論文集合本』

1 月号 Vol.19, No.1 (Ser No.66)

特集 『第19回日本雪工学会大会報告』

（）会員名簿の発行（2003年 1月）

(9)学会ホームページの更新メンテナンス

（）学会誌バックナンバーの PDF 化

\section{（6）組織委員会 （委員長・石本敬志）}

雪国における安全な移動空間の確保は, 道路, 都市, 地域計画, 建築, 医療, 社会福祉など, すそ野が広 い。また関連する機関も, 国や地方自治体, 教育研究, 街づくり等広範囲に及ぶ。各地域, 各分野で様々な 角度から雪国の移動空間確保, バリアフリ一睘境の充実に取り組んでいる個人，機関を雪工学会に迎え入れ られるよう努力したい。しかし, 団体, 個人とも, 会員数は減り続けているのが現状で次年度も一層の努力 が必要である。

（）委員会の開催

・通信による意見交換を中心とした。 


\section{(7) 学術委員会 （委員長・苫米地司）}

学術委員会では, 雪工学に関する研究の活性化を図るために, 以下のことを行った。

1) 投稿論文に対する查読委員の選定と査読依頼

2 ）大会論文募集要項の作成と大会プログラム作成

3 ）論文投稿の働きかけ

4) その他

\section{（8） 経理委員会 （委員長・田中雅順）}

平成13年度決算報告書の作成, 平成14年度の予算の立案を行い, 学会事務センター会計係と連携して, 各 会務委員会及び研究委員会等に係る平成14年度会計の出納・監督業務を行った。また，基金（特別会計）の 管理を行った。

(○委員会の開催

・第 1 回 平成 14 年 4 月 1 日 （通 信）

・第 2 回 平成 14 年 5 月 23 日 (通 信)

・第3 回平成14年6月 17 日 (通 信)

・第 4 回平成 14 年 7 月 18 日 (通 信)

・第 5 回平成 14 年 8 月 21 日 (通 信)

・第6 回平成 14 年 12 月 18 日 (通 信)

\section{(9) 研究委員会}

\section{《プロジェクト型委員会》}

\section{○建物の環境委員会 （委員長・石川善美）}

平成14年度は，これまでの活動に引き続き，積雪寒冷な気候特性に適した住宅設計のためデータベース構 築を目的として，以下のような研究活動を行った。

(1) 当委員会にて蓄積されているデータベースの充実を図るために新たに調查を実施し，実際の居住状態 での室内環境やエネルギー消費量に関する奏測調査を行つた。

(2) 構築したデータベースを用いて，住宅の居住性や室内睘境・エネルギー消費量などについて集計を行 い，積雪寒冷地に必要とされる住宅設計法を検討し，現状の問題点を把握した。

(3) 構築したデータベースをインターネット上で公開する上での運用方法や内容について再検討し，専用 Web サーバーを立ち上げ，データアプリケーションの導入を検討した。

(4) 以上の研究成果を基に, 住宅設計関連のビルダーを対象に, 仙台にて研究発表会「21世紀にふさわし い住まいと環境」（ $5 / 29$ 開催，6名の講演)，「東北地方における住宅の居住環境の現在〜熱空気環境 はどこまで改善されたか〜」（3/8 開催，5名の講演）を行うと共に，盛岡市で開催された雪工学会 大会において本委員会の成果発表（2編）を行った。

\section{○委員会の開催}

・第1回 平成 14 年 5 月 29 日（フォレスト仙台・仙台）

- 第 2 回平成 15 年 3 月 8 日 (宮城県民会館・仙台)

・その他，通信審議 


\section{屋根積雪調査委員会 （委員長・鈴谷二郎）}

E-mail による情報交換を行っている。積雪の Modeling 研究の実状調查と実測を含めた Modeling 研究 の国際協力の進め方について再検討した。

\section{○雪と地すべり委員会 （委員長・伊藤 驍）}

1）全国各地で雪と関係して発生した地すべりについて全国各地の委員と共に資料収集し，従来に加え， 新しい資料づくりを行った。

2) 委員長が, 秋田県地すべりホームドクターであったことから秋田県森吉町で融雪期に発生した 8 世帯 23人の地すべり避難民救済策と地すべり対策事業に関し学識経験者として参加し地域社会に貢献した。

3）地すべり粘土の力学的・物理的特性に関する室内実験を前年に引き続き行い，粘土鉱物の地盤工学的 性質の研究を行った。全国各地の会員がそれぞれの地域で発生する地すべり資料を収集し，従来に加え 新しい資料作りを行つた。

4 ）研究成果の一部を国際会議や日本雪工学会等で発表した。その結果, 委員長が外国の大学からレクチャー を依頼されることになり平成15年 4 月から 6 週間タイのチュラロンコン大学に行くこととなった。

5 ）秋田県内で記録に残っている炎害地すべりを全て整理し，その災害の程度を数量的に評価する試みと して数量化理論による評価を行つた。

6 ）学会誌に講座を掲載するため, 当委員会メンバーに執筆を依頼した。講座は2003年 Vol.19，No.1〜4 の通年で揭載されることとなった。執筆者は以下の 8 名である。

伊藤 驍, 竹内篤雄, 野地正保, 武士俊也, 太田泰雄, 松浦純正, 丸井英明, 渡辺康二 @委員会の開催

・第1回 平成 14 年 8 月 30 日 （アスティ德島・德島市）

・第 2 回 平成 14 年 12 月 16 日（東生橋ビルくし文・盛岡市）

\section{○雪冷熱エネルギー利用調査委員会 （委員長・和田 惇）}

雪を冷熱エネルギーとして利用する戦略を立案するために，その学問的裹付けと社会的ニーズの掌握並び に技術開発について, それらの現状と課題を調査研究した。

\section{《情報交換型委員会》}

\section{一凍上防災委員会 （委員長・久保 宏）}

1) 講演会「熊谷浩二教授講演会」

日時：平成14年 7 月 26 日, 場所：日本鋪道秼本社会議室

2) 講習会「凍上対策に関する講習会」

日時：平成15年 1 月 23 日, 場所 : 道北地域旭川地場産業振膭センター

3) テールアルメ凍上現場追跡調查

日時：平成15年 3 月 1 日

（）委員会の開催

・第 1 回 平成 14 年 7 月 26 日

（日本鋪道侏）

·第2 回 平成 15 年 1 月 23 日 （道北地域旭川地場産業振興センター）

一その他, 通信会議随時 


\section{雪崩防災委員会 （委員長・丸井英明）}

1) インタープリメント2002への参加と欧州研究者との意見交換

・雪崩セッションにて 4 件の発表がなされた。

・テクニカルセミナーにて当委員会委員を含め約20名の雪崩研究者が集まり, 欧州の雪崩研究者と雪崩 対策について意見交換を行った。

○委員会の開催

・第 1 回 平成 14 年 10 月 15 日（長野県松本市）

\section{○道路研究委員会 （委員長・村國 誠）}

1) 2002 年雪工学会誌講座担当

テーマ 道路消融雪 1 月号 路面凍結と薬剤散布

4 月号 地下水利用

7 月号 地中熱による道路融雪技術の現状・課題・展望

10月号 講座のとりまとめ 課題の整理
村國 誠 沼澤喜一 福原輝幸 上石 勲

2） SRニュースの発行 SRニュース No.3 2002年11月21日 $\mathrm{SR}$ ニュース No.4 2003年 1 月30日

3 ) 岩手大会パネルディスカッションの担当

予想以上の参加者で, 発表会の要旨を集め, 当日参加者に配布した。 （）委員会の開催

- 第 1 回 平成 14 年 12 月 17 日 (岩手大学工学部)

議題 : パネルディスカッションの反省

今後の活動について（H15年学会誌講座担当について）

(10) 平成14年度日本雪工学会賞の選考と表彰

学 術 賞 東北工業大学教授 沼野夏生

業績名：豪雪地帯における雪水防災に向けた人文社会科学的研究

北海道大学教授 城 攻

北海学園大学教授 桜井修次

業績名：効率的な積雪深観測法および信頼性の高い積雪重量推定法の開発

学術奖励賞 山形大学助手 渡邊 洋

業績名：地中熱を活用した融雪と路面温度制御に関する研究

（11）上信越支部 （支部長・宮内信之助）

1) 支部総会、役員会等

○総 会 日 時: 平成 14 年 8 月 9 日

場 所：長岡技術科学大学 機械系会議室

O役員会 開催 7 回

2 ）研究発表会

- 第 2 回研究発表会

日 時: 平成 14 年 8 月 9 日

場 所：長岡技術科学大学 機械系会議室 
3) シンポジウム等

i ) 系魚川雪シンポジウム

日 時：平成 14 年 11 月 21 日

場 所：ビーチホールまがたま

参加者：350名

ii）長岡ニュータウン雪処理アイデア発表会

日 時: 平成 15 年 2 月 2 日

参加者 : 150 名

iii）積雪期地震防災に関する講演会

日 時：平成 15 年 2 月 20 日

場 所：与板町勤労青少年ホーム

4）表 彰

平成14年度日本雪工学会上信越支部表彰は, 下記の通り。

技 術 賞 町田 誠(町田建設侏代表取締役)

学術奖励賞 富永祜秀 (新潟工科大学工学部助教授)

地域振興賞 平田五男 (北陸地方整備局長岡国道事務所所長)

能登優一（北陸地方整備局長岡国道事務所副所長）

木村浩和（侏北陸建設弘済会主任）

山田高史（俐北陸建設弘済会主任）

地域振興賞 丸山敏介（新潟電機侏代表取楴役）

\section{(12) 講 演 会 等}

1）日本雪工学会平成14年度総会特別講演会「米国の山岳部を通過するハイウエイの雪水対策」

主 催 本 会

日 時 平成 14 年 6 月 14 日

場 所 東北大学工学部青葉記念会館

参加者 30 名

2 ）公開シンポジウム企画「東北地方における住宅の居住環境の現在

$$
\text { 〜熱空気環境は何処まで改善されたか〜」 }
$$

主 催 本会建物の環境研究委員会

日 時 平成 15 年 3 月 8 日

場 所 宮城県民会館

参加者 38 名

\section{(13) 共催及び後援事業}

○共 催

1) 糸魚川雪シンポジウム

主 催 糸魚川市, 本会上信越支部

日 時平成 14 年 11 月 21 日

場 所 ビーチホールまがたま（糸魚川市） 
○後援・協賛

1) 第 4 回全国明るい雪自治体会議

主 催 雪サミット2002 in びばい

日. 時 平成 14 年 7 月 6 日 7 日

場 所 美唄市民会館

2）第10回雪だるま大賞

主 催 損雪だるま財団

3）平成14年度「雪崩防災週間」

主 催 国土交通省, 都道府県

日 時 平成 13 年 12 月 1 日 7 日

\section{(14) 学会誌等の発行}

・学会誌第 18 巻 第2 号 (Ser No.63)

- "

3 号 (Ser No.64)

4 号 (Ser No.65)

(第19回日本雪工学会大会論文報告集合本)

- 学会誌第 19 巻 第 1 号 (Ser No.66)

$\begin{array}{rr}\text { 平成 } 14 \text { 年 } & 4 \text { 月 } \\ " & \text { 月月 } \\ " & 10 \text { 月 }\end{array}$

平成 15 年 1 月

(15) 会 員 数（平成 15 年 3 月 31 日現在）

- 名誉会員 7 名

・個人会員 481 名

·学生会員 13 名

·団体会員 155 名

- 賛助会員 3 名 


\section{平成 14 年度決算書}

自 平成14年 4 月 1 日

I. 一般会言十

至 平成15年 3 月31日（単位：円）

収入の部

\begin{tabular}{|c|c|c|c|c|}
\hline 目 & 頼 & 筫 & 增 & 備 \\
\hline & $8,123,800$ & 7.247 .000 & 876,800 & \\
\hline & $2,683,800$ & $2,649,000$ & $\mathbf{3 4 , 8 0 0}$ & 納入率91.8\%(過年度含む) \\
\hline & 30,000 & 18,000 & $\triangle 12,000$ & 納入率 $46.2 \%$ (過年度含む) \\
\hline & $5,010,000$ & $4,280,000$ & $\triangle 730,000$ & 釈入率 $92.0 \%$ \\
\hline & 400,000 & 300,000 & $\triangle 100,000$ & 3 社 4口 \\
\hline$\lambda$ & 70.000 & 62.000 & $\Delta 8.000$ & 39 名 \\
\hline 誌 & 160,000 & 140,010 & $\Delta 19,990$ & \\
\hline 論文別刷尝 & 100,000 & 171,000 & 71,000 & \\
\hline 料 & 375,000 & 500,000 & 125,000 & 会誌広告および会員名海広告 \\
\hline 総会被親会 & 40,000 & 44,000 & 4.000 & 22名分 \\
\hline 利子・利 & 100 & 30 & $\Delta 70$ & \\
\hline 收 & 0 & 0 & 0 & \\
\hline 当年度収 & $8,868,900$ & $8,164,040$ & $\triangle 704,860$ & \\
\hline 前年度緦越 金 & 518,485 & 518,485 & 0 & \\
\hline & 9.387 & $8,682,525$ & $\Delta 704,860$ & \\
\hline
\end{tabular}

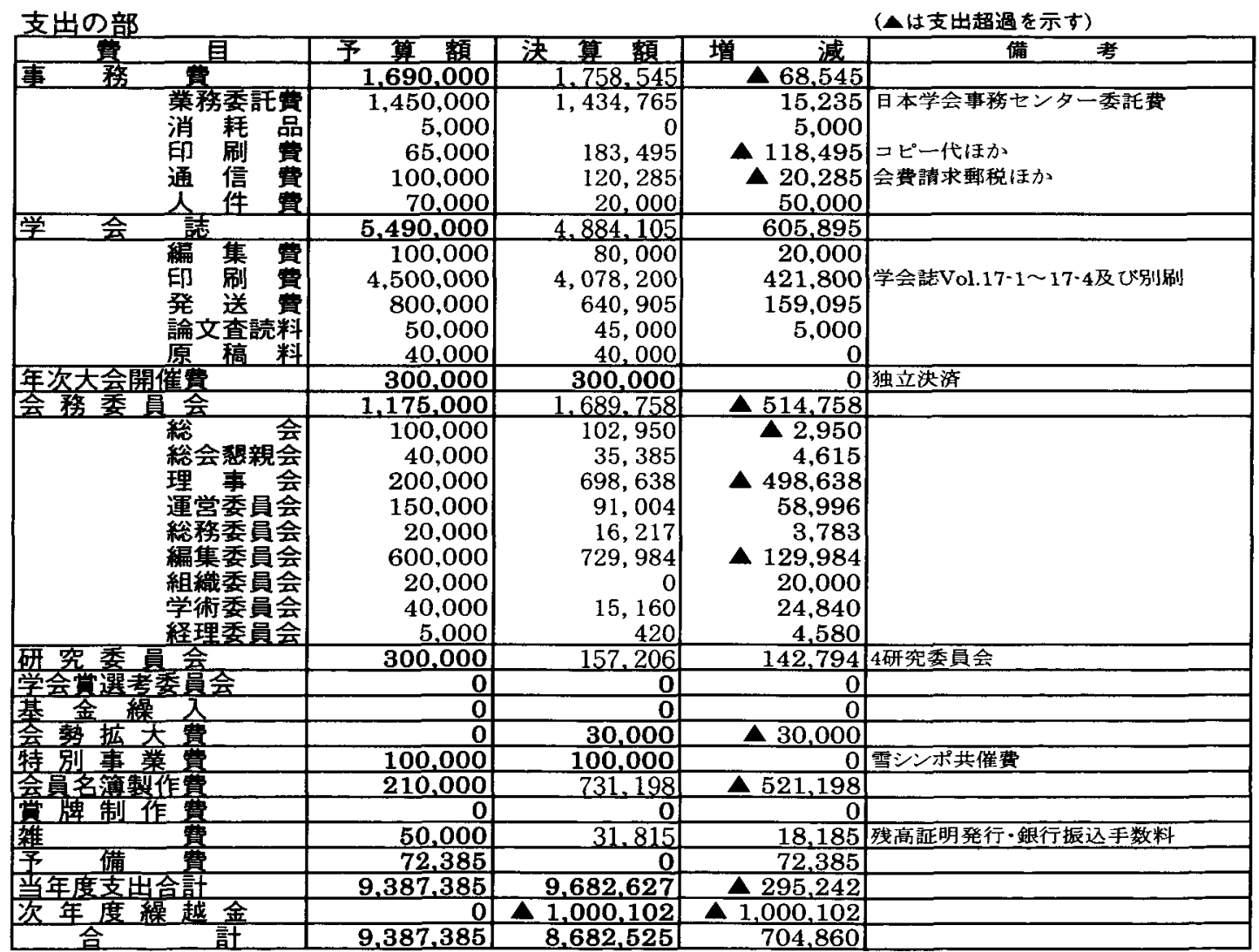

II. 基金程立（特別会計）

\begin{tabular}{|c|c|}
\hline 前年度繰越金 & $9,205,669$ \\
\hline 一般会計からの稆入 & $\mathbf{0}$ \\
\hline 利 & 8,009 \\
\hline 言† & $9,213,678$ \\
\hline
\end{tabular}

\section{会 計 監 査 報 告 書}

会計監査の結果，平成14年度决算書の内容に相違ないことを報告します。

日本雪工学会・会計監事 三崎安則 - 竹屋 明 


\section{平成 15 年度事 業計画}

\section{【運営方針】}

従来の多くの雪害を教訓とした雪害対策と豪雪地帯の快適な生活環境づくり, 特に高齢者人口の增加や産 業構造の変化等に対応した地域づくり, 雪の利用と地域振興に関する調查・研究と技術開発の一層の推進を 図り，社会に貢献する。

(1) 総会

日 時: 平成 15 年 6 月 26 日 $14: 00 \sim 16: 30$ (記念講演含)

場 所：東北大学青葉記念会館

\section{(2) 理 事 会}

・理事会の開催 3 回 (通信理事会法随時)

\section{（3）運営・会務委員会}

我国唯一の雪工学に関する学術研究団体としての特色を持った事業活動の推進を図るべく運営を企画し, また，会員の増加と組織の充実を図る。主な事業計画は以下の如くである。

1）学会誌の内容の充実，特に論文・技術報告・各委員会報告等の揭載数の増加と情報の収集等を通して 会員の参加・交流を図る。また，そのためにもホームページの一層の充実を図る。

2 ）法人化の必要条件に関する個人会員の増加と学会財政基盤の整備, 研究活動の推進を図るための重点 事業を企画し，成果の社会への還元を図る。

3 ) 各種委員会事業

@各委員会の開催予定

・運営委員会 3 回・総務委員会 3 回

・編集委員会 4 回組織委員会 3 回

- 学術委員会2 2 回・経理委員会 2 回

会務委員会の具体的な事業計画は以下の通りである。

\section{○総務委員会}

1）各種内規類の整備

2) 雪工学会アクションプランの検討

3) 各地域のニーズの調查と各種イベントの企画提案

4) 運営委員会・理事会の開催準備等

5）事務局業務の遂行

\section{○編集委員会}

1) 学会誌の編集・発行 4 回

2) ホームページの更新メンテナンス

3 ) 日本雪工学会誌バックナンバーの CD-ROM 出版 


\section{○組織委員会}

団体・個人とも, 会員数は減り続けているのが現状で一層の努力が必要である。日々, 委員が率先して努 力することとして,

・未加入団体, 個人への働きかけ強化

・異動に伴う連絡先変更の徹底

・会費未納, 滞納会員への㗢きかけ強化

・雪氷工学関連資料の共有・高度利用にからめた組織強化

\section{○学術委員会}

1）投稿諭文に対する查読委員の選定と查読依頼

2 ）大会論文募集要項の作成と大会プログラムの作成

3 ）論文投稿の働きかけ

4) その他

\section{○経理委員会}

1 ）平成14年度決算報告書の作成

2 ）平成15年度予算の立案

3）各会務委員会および研究委員会に係る平成15年度会計の出納および監督

4 ）基金（特別会計）の管理

5 ）収支悪化抑制策として，会費値上げの是非などについての検討

\section{(4) 研究委員会}

\section{《プロジェクト型委員会》}

\section{○建物の環境委員会 （委員長・石川善美）}

(1) 雪寒冷地における様々な住宅デー夕の充実を図るために, 実際の居住状態での室内環境やエネルギー 消費量に関する実測調査を行う。

(2) 当委員会において継続して構築しているデータベースを用いて, 住宅の居住性や室内環境・エネルギー 消費量などについて集計を行い，積雪寒冷地に必要とされる住宅設計法を検討し，現状の問題点を明ら かにした。

(3) データベースの活用方法について検討を行うと共に, データベースをWeb 上へ公開し，その有効性 や問題点を把握する。

(4) 得られた成果に基づき公開シンポジウムを開催し, 積雪寒冷地の住宅環境への関心を高めるよう効果 的な情報発信に努める。

\section{○屋根積雪調查委員会 （委員長・鈴谷二郎）}

Modeling 実験の検討に有効な実測資料を得て，Modeling 手法の検討を進める。また，その為の国際協 カチームを編成する。 
○雪と地すべり委員会 （委員長・伊藤 驍）

(1) 学会誌に講座「融雪期の地すべり〜地域特性からの検討〜」をVol.19 No.1に揭載したが, 引き続 き今年度も掲載し，8名の会員が執筆する。今年度の会誌への掲載は，Vol.19,No.2 No.4 となり，通 算 1 年間にわたる。

(2) 雪と関連して発生した地すべり研究成果が国際会議で認められ, タイのチュラロンコン大学でセミナー を行うこととなった。この為, 平成15年 4 月 1 日から 6 週間, 本会委員長 (伊藤驍) が海外で研究教育 活動や調查活動を行う。また, 平成15年12月より1ヶ月間, インドネシアのバンドンにあるインドネシ ア国立科学研究所で地すべり共同研究推進のため, 国際共同研究プロジェクトを検討する。

(3) 前年度に引き続き, 融雪水と地すべり粘土の挙動を解明するため, 地すべり現地から地すべり粘土試 料を採取し,その力学的挙動に関する研究を行う。

(4) 雪と関連して発生したと考えられる地すべり資料を昨年に引き続き収集し，その災害の地域的特徵等 について調査する。

(5) 第三紀層グリーンタフ地帯で発生する融雪期の地すべりと構造線沿い変成岩地带で発生する地すべり との相違の比較検討を行う。

(6) 予定成果：(1)地すべりと雪の係りが地域的に解明できると共に, 地域的な発生機構の相違などについ て分析可能となる。

(2)発生機構の解明によって, 雪国の防災対策に貢献できる。

\section{《情報交換型委員会》}

一凍上防災委員会（委員長・久保 宏)

(1) 委員会開催 3 回予定

(2)「道路と凍上に関するシンポジウム」の開催

(3)「凍上対策に関する講習会」の開催

(4)「凍上関保の講演会」第 1 回 (JH 横田工事長) ·第 2 回（未定）

○雪崩防災委員会（委員長・丸井英明）

(1) 平成16年 3 月に雪崩災害防止・軽減に関する研究会並びに委員会の開催を予定。

(2) 雪崩発生事例を収集整理する。

（5）平成15年度日本雪工学会賞の募集，選考之表彰（選考委員長・苫米地司）

（6）上信越支部 （支部長・宮内信之助）

1) 支部総会

日 時: 平成 15 年 8 月 8 日（金） 11 時〜

場 所: 長岡技術科学大学

2) 役員会 5 回

3) 表彰

地域振興賞, 功労賞, 学術賞 (支部総会当日に表彰)

4) シンポジウム（予定）

第19回越路雪シンポジウム（交流・創発 一人と川と刻の交わり一）

日 時：平成 15 年 11 月 14 日（金）

場 所：越路町総合福祉センター及び保険センター

越路町, 日本雪工学会共催 
5)支部研究発表会
日 時:未定
場 所：未定

(7) 年 次大会（第 20 回大会）

日 時: 平成 15 年 12 月 $4 \sim 5$ 日

場 所：日本大学工学部ハット NE（郡山市）

(8) 学会誌等の発行

1) 学会誌

4 月号 (Vol.19, No.2, Ser No.67) 特集『雪国における防災』

7 月号（Vol.19，No.3，Ser No.68）特集『雪国から考えるユニバーサルデザイン』

『平成15年度日本雪工学会総会報告』

10 月号 (Vol.19, No.4, Ser No.69) 特集『冬期道路情報管理』

1 月号（Vol.20, No.1, Ser No.70）特集『日本雪工学会設立20周年記念号』

2）その他

（9）特別事 業

- 講演会等の主催, 共催 


\section{平成 15 年度予算(案)}

自 平成15年 4 月 1 日

至 平成16年 3 月 31 日 (単位：円)

I. 一般会計

\begin{tabular}{|c|c|c|c|c|}
\hline 入の部 & & & & (ムは予算滅を示す) \\
\hline 目 & 平成14年度 & 平成15年度 & 減 & 備 \\
\hline 会 & 8.123 .800 & 7.616 .800 & $\triangle 507,000$ & \\
\hline & $2,683,800$ & $2,521,800$ & $\Delta 162,000$ & $6,000 \mathrm{H} \times 467$ 名 $\times 90 \%$ \\
\hline & 30,000 & 45,000 & 15,000 & 3,000 月 $\times 15$ 名 \\
\hline 员会蜜 & $5,010,000$ & $4,650,000$ & $\Delta 360,000$ & $30,000 円 \times 155$ 口 \\
\hline 会當 & 400,000 & 400,000 & 0 & 3 社4口 \\
\hline $\bar{\lambda}$ & 70,000 & 60,000 & $\mathbf{A} 10.000$ & 目標会員数 30 名 \\
\hline 売 & 160,000 & 150.000 & $\Delta 10,000$ & 前年度疌續による隇額 \\
\hline 敦侖文別刷売上 & 100.000 & 150,000 & 50,000 & 前年度実縝による堌額 \\
\hline 広 & 375,000 & 200,000 & $\triangle 175,000$ & \\
\hline 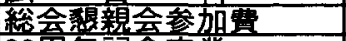 & 40.000 & 40,000 & 0 & \\
\hline 20周年記念事菜 & 0 & 500,000 & & 学会誌バックナンバーCD売上 \\
\hline 利子・利息 & 100 & 30 & $\Delta 70$ & \\
\hline$\sqrt{2}$ & o & 0 & 0 & \\
\hline 当年度収入合計 & $8,868,900$ & $8,716.830$ & $\Delta 152,070$ & \\
\hline 基金からの絽入 & 0 & $2,000,000$ & & 借金返済，20周年記念事業のため \\
\hline 前 年 度 䍃越 & 518,485 & $\Delta 1,000,102$ & $\Delta 1,518,587$ & 事務センターがら借入 \\
\hline 合 & $9,387,385$ & $9,716,728$ & 329,343 & \\
\hline
\end{tabular}

\begin{tabular}{|c|c|c|c|c|}
\hline 又 & & & & (ムは予算減を示す) \\
\hline 䨳 & 平成14年度 & 平成15年度 & 壃 & 備 \\
\hline 事 & $1,690,000$ & $1,660,000$ & $\Delta 30,000$ & \\
\hline & $1,450,000$ & $1,450,000$ & 0 & 日本学会事務センター委託费 \\
\hline $\begin{array}{l}\text { 消 耗 品 } \\
\text { 印 刷 整 }\end{array}$ & 5,000 & 5,000 & 0 & . \\
\hline 通信 贯 & $\begin{array}{r}60,000 \\
100,000\end{array}$ & $\begin{array}{r}65,000 \\
120,000\end{array}$ & 20000 & 前年度冢緽に基づく增積 \\
\hline 件 書 & 70,000 & 20,000 & $\begin{array}{r}20,000 \\
\end{array}$ & 前年度実續に基つく減額 \\
\hline 学 & $5,490,000$ & $5,020,000$ & $\triangle 470,000$ & \\
\hline 集 & 100,000 & 80,000 & $\Delta 20,000$ & 前年度実績に基づく淢額 \\
\hline 刷 寒 & $4,500,000$ & $4,200,000$ & $\Delta \mathbf{3 0 0 , 0 0 0}$ & 学会誌Vol.19及び別刷 \\
\hline & 800.000 & 650,000 & A 150,000 & 前年度沣績に基づく減額 \\
\hline 論文查融料 & 50,000 & 50,000 & 0 & \\
\hline 料 & 40,000 & 40,000 & 0 & \\
\hline 年次大 & 300,000 & 500,000 & 200,000 & \\
\hline 会雅委員 & $1,175,000$ & $1,085,000$ & $\triangle 90,000$ & \\
\hline 会 & 100,000 & 100,000 & 0 & \\
\hline 見会 & 40,000 & 40,000 & 0 & \\
\hline & 200,000 & 200,000 & 0 & \\
\hline 運棠娄員会| & 150,000 & 100,000 & A 50.000 & 前年度実績に基つく減額 \\
\hline 谷務委員会 & 20,000 & 20,000 & 0 & \\
\hline 谝集委員会 & 600,000 & 600,000 & 0 & \\
\hline 委員会| & 20,000 & 20,000 & 0 & \\
\hline 委員会| & 40,000 & & $\Delta 40,000$ & 委員会小口現金を使用 \\
\hline 会 & 5,000 & 5,000 & of & \\
\hline & 300,000 & 250,000 & $\triangle 50,000$ & \\
\hline 員会 & 0 & 0 & 0 & \\
\hline 基 & 0 & 0 & 0 & \\
\hline 会勢拡太 & 0. & 50,000 & 50,000 & 增収対策费 \\
\hline 特別事業害 & 100,000 & 100,000 & 0 & シンボジヴ共催䨘 \\
\hline 会曼名簿制作費 & 210,000 & 0 & $\triangle 210,000$ & \\
\hline 20周年記念事業害 & 0 & 900,000 & 900,000 & 学会誌バックナソバーCD化 \\
\hline 賞牌制作寒 & 0 & 0 & 0 & \\
\hline 䛼 & 50,000 & 50,000 & о & 送金手数料など \\
\hline 学 & 72.385 & 101,728 & $2 \overline{9}, 343$ & \\
\hline 註 & 9.387 .385 & $9,716,728$ & $\triangle 329,343$ & \\
\hline
\end{tabular}

\begin{tabular}{|c|c|}
\hline 前年度繰越金 & $9,205,669$ \\
\hline 一般会計からの策入 & 0 \\
\hline 一般会計への練出 & $2,000,000$ \\
\hline 和 & 0 \\
\hline 許 & $7,205,669$ \\
\hline
\end{tabular}




\section{日本雪工学会平成15年度総会＼cjkstart記念講演}

\section{社会的ジレンマとしての雪問題（講演概要）}

原文 宏*

Fumihiro Hara

\section{1.はじめに}

冬期道路管理や雪問題に関する住民要望や除雪に 関する苦情の中には，住民個々の利益（私益）を最 大化することが目的になっているために, 結果とし て公共の利益（公益）が損なわれるケースが見られ る。いわゆる社会的ジレンマといわれる問題である。 社会的ジレンマは，現行の除雪技術や雪対策時術 では解決が難しく, 個々人の態度変容を促すことが 解決に向けた抜本的な対策と考えられている。しか し, 態度変容を促す手法は, 未だ研究段階であり, 教育や社会心理学的アプローチによる試行がはじまっ たばかりである。

\section{2. 社会的ジレンマと考えられる雪問題}

札幌等の北海道の都市における，なかなか解決で きない雪問題について, 特に社会的ジレンマに分類 されると考えられる問題を抽出すると，以下のよう に整理される。

（1）個々人の防寒対策低下と除雪・防寒対策費の増加

（2）冬期路上駐車による除雪作業の支障, 遅延

（3）住民の車道への雪出しによる路面悪化

（4）雪捨てによる小河川の洪水

（5）雪捨て場でのゴミの集積

(6) 豪雪時の自動車利用

\section{3. 社会的ジレンマの解消}

藤井は ${ }^{11}$ 社会的ジレンマの解消に関する既存研 究を整理して, ジレンマ問題の解消方法を以下の 2 つに区分している。

ここで, 非協力行動とは, 個々人の利益の最大化 行動（全員が自らの行動を変えない）を意味し，公
共利益の最大化行動を協力行動（全員が多少の行動 变化を受け入れる）と呼ぶ。

協力行動をとる人を多くするためには，「教育」に よって利己主義を排し，公益に対して協力的な行動 をとる人間を育成することが基本であるが，教育に はムラがあり，かならず非協力行動をとる人が現れ る。そのような人には，別な手法で対応する必要が ある。方法は 2 つ, 構造的方略と心理的方略である。 構造的方略：法的規制により逃避行動を禁止する。 例えば法的な規制によって，逃避行動をとる人に罰 則を課したり，逃避行動をとらない場合にインセン ティヴを与えたりする。

心理的方策 : 個人の行動を規定している信念, 態度, 責任感, 信頼, 道徳心等の心理要因に働きかけるこ とで, 自発的な協力行動を誘発する。

\section{(1) 教育}

小学校の社会科及び理科の教科書を対象に雪や除 雪に関する記述を調べてみると，教科書や製作され る年代によって量的にバラバラである上に，雪に関 わる伝統行事や祭り，スポーツに関わる内容が多く, ジレンマ的な雪問題をテーマにしたものはなかつた。

最近は「総合的な学習の時間」が設けられ, 体験, 地域，国際，環境などがキーワードとなっている。 そのせいか，地域や環境に興味を持つ小学校教諭か ら雪や除雪をテーマにした学習について問い合わせ があり $2 ， 3$ の学校で除雪や雪に関するモデル授業 を実施し，その前後に心理指標による調査を奏施し た結果, 効果を確認することができた。

\section{(2) 構造的方略}

構造的方略は，アメ(報酬) とムチ（罰）によっ て逃避行動を押さえる方策である。現在実施されて

* 社北海道開発技術センター理事 
いる方策として，冬期路上駐車禁止地区の拡大, 町 内会によるゴミ出し時間の指導程度である。

また，報酬を与える戦略として，冬に適したファッ ションやデザイン開発機関の表彰, パーク＆ライド 駐車場の利用料金の減免, バスや地下鉄料金の減額 等の公共交通優遇策がある。いずれも，法的な拘束 力が弱く, インセンティヴとして鬽力的でないため に，うまくいっているとは言い難いのが現状である。 ただし，構造的方略によって法的規制（罰）があ まりに強化されると統制的な息苦しい社会になって しまう可能性があるほか，報酬を与えすぎても，自 主的に協力するという内発的な動機付けを下げる結 果となる。したがって，罰と報酬のタイミング，量 等のバランスが重要である。

(3) 心理的方略

心理的方策は，個々人の自主的な行動変容を誘発 する万策であり，一般的には PR，キャンペーン, 広報が行われている。雪問題でも路上駐車, 車道, 河川への雪だし禁止の広報, 豪雪時のマイカー利用 自肃の呼びかけ等が定期的に行われているが，その 効果ははっきりしない。

藤井 ${ }^{2)}$ が交通施策としての心理的方略を分類し ており，情報提供法，低頼法, 行動プラン法, フィー ドバック法，アドバイス法等がある。いずれの方法 も実証的な検証が行われて, 有効性は確認されてい る。

人間の行動が変化するプロセスとして, まず行動 意図（雪問題に配慮した行動をしよう）が生まれ， その後実行意図（例えば道路への雪出しを止めて敷 地内に堆積しよう）が形成されて，実際に行動する としている。この各段階に適用すべき心理的方策と しては, 行動意図（依頼法, 情報提供法, フィード バック法), 実行意図 (行動プラン法, アドバイス法) 等が效果的といわれている ${ }^{2)}$ 。事実, 谷口他 ${ }^{3.4)}$ が, 個別的なフィードバック法とアドバイス法を組み合
わせた心理的 TDM 施策 “TFP（トラベルフィー ドバックプログラム)" の開発と効果の検証を行つ ており，その効果と継続性を確認している。

\section{4.おわりに}

多くの社会的ジレンマとしての雪問題が存在する が，適切な対策が見いだせていない。現在実施して いる構造的方略は, 規制としての拘束力が弱く, 実 效性にかけるため, 実効性のある構造的方略の開発 研究が必要である。(アメとムチのバランス)

また, 心理的方略を基本に構造的方略を進める必 要がある。心理的方策の有効性は検証されており, 雪問題への具体的な適用手法の開発が課題である。 心理的方略の具体的な展開として,「学校を中心と した地域」のようなフレームとの連携が有効である。 ただし，学校教育本来の使命を基本とした連携体制 を心がける必要がある。

\section{【参考文献】}

1) 藤井 聡：TDM と社会的ジレンマ: 交通問題 解消における公共心の役割, 土木学会論文集, No.667/IV-50, pp41-58, 2001

2) 藤井 聡 : 行動プラン法による行動変容, 土木 計画学研究・講演集 (秋大会) CD-ROM, 2002

3 ) 谷口綾子, 原 文宏, 高野伸栄, 加賀屋誠一: TDM の心理的方略 “TFP” の効果継続性に関 する研究，土木計画学研究・講演集 (春大会) CD-ROM, 2002

4) 谷口綾子, 原 文宏, 村上勇一, 高野伸栄： TDM を目的とした交通行動記録フィードバッ クプログラムに関する研究－札幌市におけるト ラベルブレンディングプログラム的実験 - , 土 木計画学研究・論文集, 2001, 18(5), pp895902 